\title{
THE BIBI CAMP AND THE TREK ACROSS THE PLAINS
}

By O. J. PruitT

Curator Pottawattamie County Historical Society

The Bibi camp, composed of thirteen small log cabins, was built to house people who were gathering to journey either to Washington, Oregon, California, or Salt Lake, Utah. The site of this camp was on the Joseph Thomas farm, on Section 33, in Boomer township, of Pottawattamie county.

Mr. Thomas was born in Salt Lake and returned to Iowa in 1866. He saw his first train, on the Union Pacific, at Kearney, which was the west end of the road at that time.

A few of the log cabins of the camp existed until 1872. The last one was destroyed by fire built by two hunters, George Morrison and Chief Mud Turtle of the Winnebago tribe. The cabins were occupied by some for nearly two years, until a train of thirty wagons or more could be assembled. Each party or family had to have six months supply of clothing, food, and medicine, and two yoke of oxen, one hundred dollars in cash, and a milk cow.

"Bilge" Bibi was of average height, but with an extended abdomen, and this was the reason for his nickname. History fails to record his given name.

The party included Ira Stevens, the Mueller brothers, John Payne, Bledsoe McIntosh, James Stockton, Joseph Sharp, Moses Steck, Isaac Buckley, August Swartheim and many others whose names and whereabouts are unknown. Data obtainable fails to mention any other names than those quoted.

When the party was all set to go they drove to the Missouri river to cross at the Mormon ferry at Florence. They camped there to await their turn to cross. The Bibi start was only a few days ahead of that of Orson 
Hyde and Johnson. Johnson was the publisher of the Bugle. Johnson, with his two wives and fourteen children, and an adopted niece, Rosa Smith, required two wagons to hold the family and household goods and provisions. It is not definitely known whether Bibi later joined this train, but it is known he awaited the growth of the grass at Florence.

There are three mines named Swart in California, and it is probable that August Swartheim was responsible for their location. He was a mining engineer, being a native of Pennsylvania.

The Mueller brothers and Bledsoe McIntosh after reaching Salt Lake began a return trip by a circuitous route. Driving a span of horses hitched to a spring wagon, they veered north through Wyoming and were waylaid by Indians. They escaped by abandoning the team and wagon. Upon reaching the Niobrara river, they built a log raft and floated down the river to Sioux City. From there, they returned by stage to Camp Bibi. McIntosh was a farmer, and did some blacksmithing near what is now Crescent, Iowa. It is reported that at one time he owned the large tract of the land formerly owned by Johnson. Many of McIntosh's descendants live in the vicinity today.

People living along Pigeon creek in Pottawattamie county recall having heard their fathers tell of the grist mill and the Bibi camp. The cabins of the camp were scattered along North Pigeon creek. A hundred years ago, this was only a long slough, but today it becomes a roaring torrent at storm periods, with a depth of fifty feet in places.

The Winnebago Indians lived in the timber nearby. Not all the Indian relics found in that vicinity are Winnebago. Some are very old and judging from the limestone patination, some are Mandan, and others which do not have a crushed granite binder are Pawnee or Otoe. 
It is not known whether Bibi was a Mormon or not. However, he had only one wife. None of the men of the Bibi train had more than one wife.

Today a visitor to the site of the Bibi camp would see a white schoolhouse. The schoolhouse is on a playground bounded on the east by a bank of the creek thirty feet high. On the other sides are some of the tall fields of corn that make Iowa famous. One and a half miles away is the Lincoln highway, with the roar of traffic, and also the roar of passing trains on the Northwestern and Illinois Central railroads.

On the east valley walls of the Pigeon, half way up the hill, are the graves of the whites, unmarked and forgotten. One skeleton, that of a mother with her babe in arms, rests in a two inch thick homemade casket of walnut. It is now over one hundred years since its interment. The dentine is that of an adult person about twenty-four years of age. This woman is thought to have been the wife of Polk Roach, and it is thought she died in childbirth. Who or what archeologist could make a better surmise? What is left is the casket, with a few pearl buttons that crumble between the fingers. The bones tell the story outlined above. This is all that. is left of Bibi camp.

Relics collected from the site are in the Pottawattamie county historical museum, at Council Bluffs. We have there such relics as the nave and iron bands of conestoga wagons, a bull chain, some iron skillets, some old. axe bits, and some bridle bits.

\section{TEACHING OF IOWA HISTORY REQUIRED}

The teaching of Iowa history in the public schools of the state was added to the list of required subjects by the Forty-fourth General Assembly in 1931. 
Copyright of Annals of Iowa is the property of State of Iowa, by \& through the State Historical Society of Iowa and its content may not be copied or emailed to multiple sites or posted to a listserv without the copyright holder's express written permission. However, users may print, download, or email articles for individual use. 